\title{
WPLYW INSTRUMENTU QUANTITATIVE EASING REZERWY FEDERALNEJ NA WYBRANE KURSY WALUTOWE
}

Globalny kryzys finansowy, za którego symbol można uznać upadek banku Lehman Brothers, stał się dla wielu banków centralnych, w tym Rezerwy Federalnej, impulsem do zastosowania wcześniej niespotykanego na tak dużą skalę ilościowego łagodzenia polityki pieniężnej. Program skupu aktywów wywarł na rynek skutek na dwóch płaszczyznach. Z jednej strony dostarczył płynność poszczególnym segmentom rynku finansowego, a z drugiej - wpłyną na popyt nominalny, a za jego pośrednictwem przeciwdziałał załamaniu gospodarczemu w wyniku zahamowania akcji kredytowej. Jednocześnie działania te wywołały ze strony polityków i ekonomistów oskarżenia o celowe doprowadzenie do zwiększenia konkurencyjności produktów amerykańskich, w efekcie aprecjacji walut obcych.

Przedstawiona $\mathrm{w}$ niniejszym opracowaniu analiza ma na celu zbadanie wpływu zastosowania przez Rezerwę Federalna (FED) niestandardowych instrumentów z zakresu quantitative easing (QE) na kursy wybranych walut. W szczególności poszczególne fazy działań Rezerwy Federalnej, znane powszechnie jako QE1, QE2 i QE3, porównane zostaną pod kątem wywoływania efektu prowadzącego do osłabienia wartości dolara amerykańskiego i aprecjacji walut obcych $\mathrm{w}$ wyniku zastosowanego na dużą skalę zasilenia rynków finansowych. Przeprowadzona analiza umożliwi prowadzenie dalszych badań nad efektami podejmowanych przez banki centralne działań antykryzysowych.

\section{CZYNNIKI KSZTAŁTUJĄCE KURS WALUTOWY}

Nominalny kurs walutowy powszechnie definiowany jest jako cena jednej jednostki waluty wyrażona w jednostkach innej waluty. Wahania kursu walutowego moga mieć charakter aprecjacji lub deprecjacji, rewaluacji lub dewaluacji. Wzrost wartości waluty krajowej określa się mianem aprecjacji, natomiast spadek wartości - deprecjacją. Zjawiska te mają charakter rynkowy.

Poziomy kursów walut oraz ich wahania maja istotne znaczenie dla wielu elementów gospodarki krajowej. Na poziomie makroekonomicznym decyduja o strukturze bilansu handlowego danego kraju, a na poziomie mikroekono- 
micznym wpływają na zyski przedsiębiorstw zajmujących się handlem zagranicznym. Czynniki wpływające na kształtowanie kursu walutowego moga mieć charakter zarówno ekonomiczny, jak i pozaekonomiczny, jednocześnie oddziałując w krótkim lub w długim okresie. Schematycznie powiązania między czynnikami mającymi wpływ na poziom i wahania kursu walutowego oraz ich klasyfikację przedstawiono niżej (schemat 1).

\section{Schemat 1}

Główne czynniki wpływające na kursy walutowe

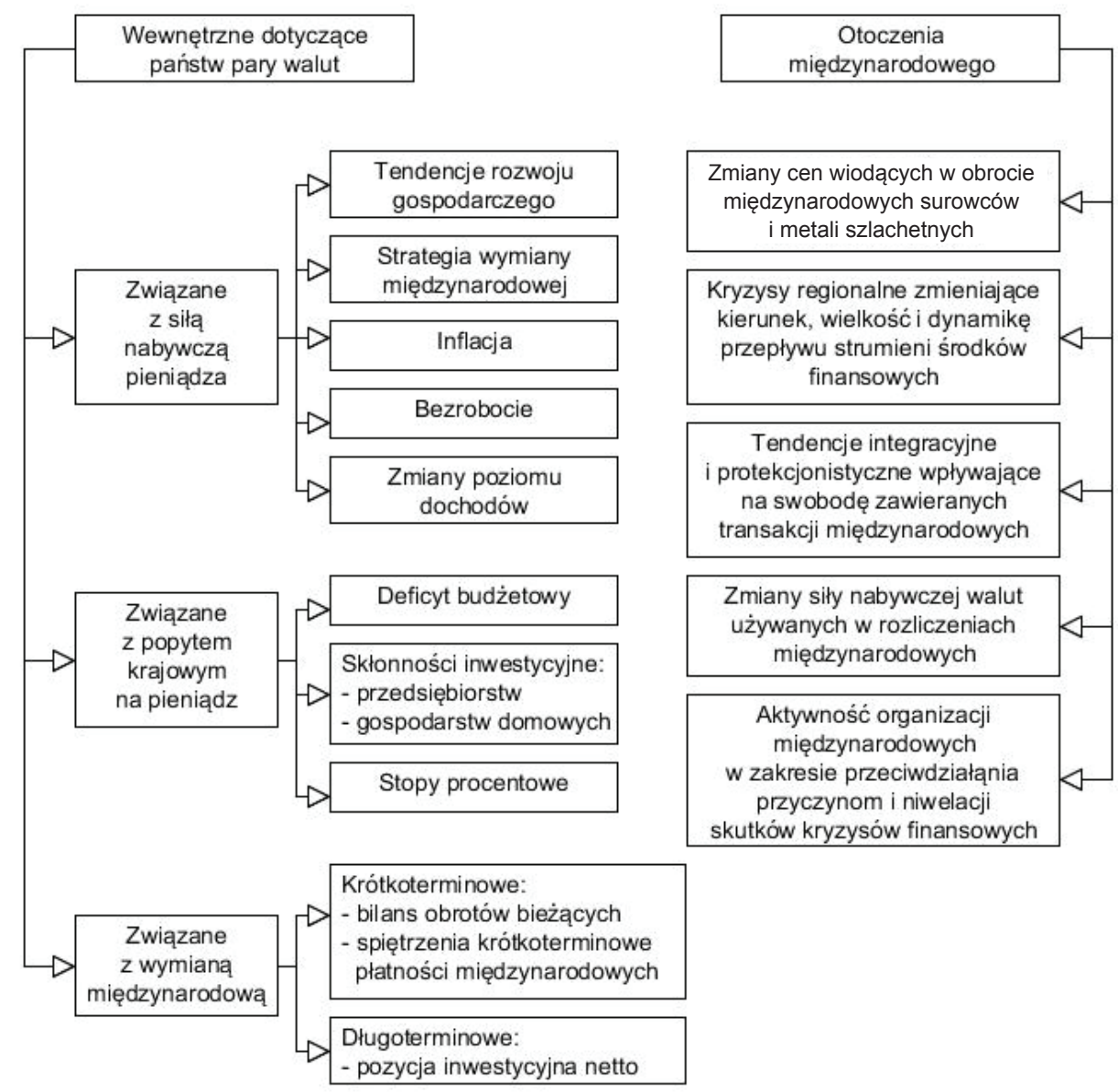

Źródło: B. Bernaś, A. Pietrzak, Kursy walutowe, w: B. Bernaś (red.), Finanse międzynarodowe, WN PWN, Warszawa 2006, s. 161.

W szczególności czynnikiem takim jest zmiana podaży pieniądza. W długim okresie wzrost podaży pieniądza prowadzi do podwyższenia krajowego poziomu cen, który z kolei powoduje spadek oczekiwanego przyszłego kursu walutowego. 
W krótkim okresie, gdy poziom cen się nie zmieni, realny wzrost podaży pieniądza wywoła spadek krajowej stopy procentowej. Neutralność pieniądza w długim okresie jest więc przyczyną zjawiska przestrzelenia kursu walutowego, polegajacego na tym, że spadek kursu walutowego pod wpływem zwiększenia podaży pieniądza jest silniejszy w krótkim niż w długim okresie i przyczynia się do obserwowanej empirycznie wrażliwości kursów walutowych ${ }^{1}$.

Wahania kursów walut, które występują na rynku, nie wykluczaja istnienia średnio- lub długookresowego kursu równowagi, który eliminowałby wpływ czynników losowych oraz cyklicznych na poziom kursu walutowego. Wśród koncepcji i modeli dążących do wyznaczenia takiego poziomu kursu zaliczyć można:

- teorię parytetu siły nabywczej,

- model kursu równowagi fundamentalnej (FEER),

- model kursu równowagi behawioralnej (BEER),

- teorię niezabezpieczonego parytetu stóp procentowych ${ }^{2}$.

\section{REAKCJA RYNKÓW FINANSOWYCH NA QUANTITATIVE EASING}

Faza początkowa globalnego kryzysu finansowego rozpoczęła się w sierpniu 2007 r., natomiast jego zasadnicza faza nastapiła po ogłoszeniu upadku banku Lehman Brothers - we wrześniu 2008 r. Początkowo odpowiedź Rezerwy Federalnej na kryzys ograniczała się do zastosowania tradycyjnych instrumentów polityki pieniężnej dostarczających płynność. Silne obniżki stóp procentowych stanowiły pierwszą reakcję banków centralnych na niekorzystne informacje rynkowe. Obniżki te nie spowodowały jednak oczekiwanych efektów w zakresie poprawy płynności, zaktywizowania rynku międzybankowego i odbudowy działalności kredytowej.

Ograniczona możliwość dalszego stosowania obniżek stóp wobec niskiego ich poziomu była przyczyną decyzji o tymczasowym zastosowaniu dodatkowych instrumentów będących realizacja polityki bilansowej. Quantitative easing (QE) to proces bezpośredniego zasilania rynków w płynność (zwiększania ilości pieniądza $\mathrm{w}$ obiegu), jak również polityka oddziaływania na rynek innymi dostępnymi drogami niż kanał stopy procentowej. Ważną cechą QE jest to, że zazwyczaj prowadzi do zwiększenia sumy bilansowej banku centralnego, a przynajmniej do zmiany struktury poprzez wzrost udziału ryzykownych i mniej płynnych aktywów w bilansie (tzw. qualitative easing) ${ }^{3}$.

${ }^{1}$ F. S. Mishkin, Ekonomika pieniadza, bankowości i rynków finansowych, WN PWN, Warszawa 2002 , s. 239-241.

${ }^{2}$ M. Rubaszek, Kurs równowagi, w: A. Sławiński (red.), Polityka pieniężna, C. H. Beck, Warszawa 2011, s. 96-104.

${ }^{3}$ W. Przybylska-Kapuścińska, M. Szyszko, Quantitative easing - niestandardowe narzędzia polityki pieniężnej $w$ architekturze rynków finansowych, w: W. Frąckowiak, J. Szambelańczyk (red.), Ku nowemu paradygmatowi nauk o finansach, Wyd. UEP, Poznań 2010, s. 193. 
Program skupu aktywów o średnim i długim okresie zapadalności, odbywający się w ramach bezwarunkowych operacji otwartego rynku (tzw. large scale asset purchases - LSAP) został zainicjowany przez Rezerwę Federalna 25 listopada 2008 r. Pierwsza faza poluzowania ilościowego (QE1) trwała do marca 2010 r., natomiast QE2 - od listopada 2010 r. do czerwca 2011 r. Ze względu na statutowy mandat dążenia do maksymalnego poziomu zatrudnienia FED zadecydowała o rozpoczęciu trzeciej fazy programu skupu aktywów we wrześniu 2012 r., która nie została jeszcze zakończona ${ }^{4}$.

Skuteczność instrumentu quantitative easing została potwierdzona w wielu pracach empirycznych. W efekcie zastosowania LSAP dokonała się redukcja długoterminowych stóp procentowych. Efektem pierwszej fazy QE było obniżenie rentowności obligacji skarbowych o 40 do 110 punktów bazowych, a fazy QE2 - obniżenie rentowności o dodatkowe 15 do 45 punktów bazowych ${ }^{5}$. Istnieją również badania potwierdzające obniżenie premii za ryzyko na rynku hipotecznym i rynku swapów. Potwierdzeniem poprawy sytuacji rynkowej był również spadek oprocentowania instrumentów stanowiących przedmiot programu LSAP, takich jak obligacje przedsiębiorstw, swapy stóp procentowych i kredyty hipoteczne ${ }^{6}$.

Luzowanie ilościowe nie doprowadziło jednak do zwiększenia agregatu pieniężnego M2, mimo przyrostu bazy monetarnej. Podobnie, wbrew obawom, nie odnotowano również znaczącego wzrostu inflacji (w $2012 \mathrm{r}$. wzrost inflacji spowodowany był wzrostem cen energii), a oczekiwania inflacyjne pozostaja na niskim poziomie (poniżej 2,5\%)

Obserwacja wzrostu PKB w USA wskazuje, że w każdej fazie QE następuje ożywienie gospodarcze, któremu towarzyszy wzrost popytu konsumpcyjnego i wzrostu wydatków w kategorii dóbr trwałych. Znaczący wpływ na poprawę nastrojów konsumentów miały niewątpliwie wzrosty indeksów cen akcji, które występowały w każdej fazie poluzowania ilościowego ${ }^{8}$.

Zwiększanie dostępnej dla systemu bankowego płynności połączone z zastąpieniem przez banki centralne rynku międzybankowego spowodowało również skutki po pasywnej stronie bilansu Rezerwy Federalnej. Istotnie wzrosła wartość rezerw utrzymywanych przez instytucje finansowe na rachunkach FED.

$\mathrm{W}$ wymiarze międzynarodowym efektów $\mathrm{QE}$ istnieją badania wpływu wdrożenia LSAP na dochodowość międzynarodowych obligacji i poziomów kursów walutowych. Komunikaty zapowiadające zamiar skupu wybranych aktywów na rynku doprowadziły do redukcji oczekiwanej długoterminowej rentowności obligacji USA, redukcji dochodowości długoterminowych obligacji zagranicznych i deprecjacji dolara amerykańskiego ${ }^{9}$.

${ }^{4}$ P. Woźniak, Długofalowe skutki polityki niskich stóp i poluzowania polityki pieniężnej, „Zeszyty BRE Bank - CASE” 2013, nr 129, s. 11-12.

${ }^{5}$ H. Żywiecka, Niestandardowe działania banków centralnych w warunkach globalnego kryzysu finansowego, CeDeWu, Warszawa 2013, s. 209.

6 Ibidem, s. 210-212.

7 P. Woźniak, op. cit., s. 12-15.

${ }^{8}$ H. Żywiecka, op. cit., s. 216.

9 C. J. Nelly, The Large-Scale Asset Purchases Had Large International Effects, Working Paper 2010-018D, Federal Reserve Bank of St. Louis, July 2010, Revised April 2012, s. 30. 


\section{METODOLOGIA BADAŃ}

Opis wpływu podjęcia przez FED działań z zakresu niestandardowej polityki pieniężnej jest wynikiem dwutorowej analizy z wykorzystaniem narzędzi ekonometrycznych. W ramach pierwszego toru analizy dokonuje się wskazania modelu kształtowania się zwrotów z kursów walutowych z dodatkowymi zmiennymi w równaniu modelu. Istotność oszacowań parametrów tych zmiennych jest przedmiotem analizy, gdyż pozwala wnioskować, czy zjawisko opisane dodatkową zmienną ma wpływ na badaną zmienna. Drugi tor analizy polega na wykorzystaniu testu przyczynowości Grangera w celu ustalenia związku między badanymi szeregami, a w przypadku wykrycia zależności przedstawienie jej w postaci modelu VAR.

Do narzędzi współczesnej ekonometrii z powodzeniem włączono modele z klasy ARMA i GARCH, które pozwalają na sformułowanie modeli szeregów wykazujących liniowe (autokorelacja) oraz nieliniowe (autokorelacja w szeregu kwadratów zwrotów) zależności. Modele ARMA to liniowe modele powstałe z połaczenia modeli autoregresyjnych AR i modelu średniej ruchomej MA. Modele GARCH pozwalają uwzględnić zmienność rozumiana jako wariancja warunkowa stopy zwrotu. Połączenie wcześniej wspomnianych modeli ARMA i GARCH pozwala przedstawić zwrot jako sumę wartości średniej warunkowej opisanej modelem ARMA oraz reszty (szoku), której zmienność opisana jest modelem $\mathrm{GARCH}^{10}$ :

$$
\begin{aligned}
& r_{\tau}=\mu_{\tau}+y_{\tau} \\
& y_{\tau}=\sigma_{\tau} \varepsilon_{\tau} \\
& \sigma_{\tau}^{2}=\omega+\sum_{i=1}^{q} \alpha_{i} y_{\tau-i}^{2}+\sum_{j=1}^{p} \beta_{j} \sigma_{\tau-j}^{2}
\end{aligned}
$$

$\operatorname{gdzie} \varepsilon_{\tau} \sim \operatorname{iid}(0,1), \omega>0, a_{i} \geq 0$ oraz $\beta_{j} \geq 0$.

Umieszczenie w równaniach średniej warunkowej oraz zmienności dodatkowych zmiennych objaśniających przekształca model do postaci:

$$
\begin{aligned}
& r_{\tau}=\mu_{\tau}+y_{\tau} \\
& y_{\tau}=\sigma_{\tau} \varepsilon_{\tau} \\
& \sigma_{\tau}^{2}=\omega+\sum_{k=1}^{m} \omega_{k} s_{k, \tau}+\sum_{i=1}^{q} \alpha_{i} y_{\tau-i}^{2}+\sum_{j=1}^{p} \beta_{j} \sigma_{\tau-j}^{2}
\end{aligned}
$$

${ }^{10}$ M. Doman, R. Doman, Modelowanie zmienności i ryzyka, Oficyna a Wolters Kluwer business, Kraków 2009, s. 75-85. 
gdzie $x_{i, \tau}$ oraz $s_{k, \tau}$ są dodatkowymi zmiennymi objaśniającymi. W ramach pierwszego toru analizy do równania średniej i wariancji warunkowej wprowadzone zostaną najpierw zmienne zero-jedynkowe, które wychwyca strukturalne zmiany w modelu w okresach trwania poszczególnych faz QE, a następnie zmienna będąca stopa przyrostu stanu bilansowego aktywów FED. Istotność zmiennych w równaniu średniej lub wariancji warunkowej oznacza, że istnieje statystycznie istotny wpływ badanej zmiennej na wzrosty lub spadki stóp zwrotu z kursu lub na wartość zmienności w poszczególnych fazach QE.

Drugi tor analizy opiera się na analizie przyczynowości zdefiniowanej przez Clive'a W. J. Grangera ${ }^{11}$. Mówimy, że zmienna $x$ jest przyczyną w sensie Grangera dla zmiennej $y$, jeśli uwzględnienie w modelu objaśniającym $y$ opóźnionych wartości zmiennej $x$ do rzędu $k$ włącznie poprawia jakość wnioskowania (modelowania, prognozowania) o zmiennej $y$. Konstrukcja testu sprawdzajacego przyczynowość polega na zbudowaniu regresji objaśniającej $y$, zawierającej opóźnione wartości $x$, a następnie testowanie łącznej istotności tych opóźnień. Jest to tzw. test Grangera przyczynowości w sensie Grangera. Jeśli w równaniu:

$$
y_{\tau}=\sum_{i=1}^{k} \alpha_{i} y_{\tau-i}+\sum_{i=1}^{k} \beta_{i} x_{\tau-i}+u_{\tau}
$$

$\beta_{i}=0(i=1,2, \ldots, \mathrm{k})$, to $x_{t}$ nie jest przyczyną $y_{t}$. Rząd opóźnienia $k$ jest arbitralny ${ }^{12}$. W opracowaniu za zmienna $y$ przyjęte zostaną szeregi zwrotów z kursów poszczególnych walut, natomiast za zmienna $x$ - stopa przyrostu stanu bilansowego aktywów FED.

Dla tych kursów walut, dla których stopa przyrostu wartości papierów wartościowych w FED stanowi przyczynę w sensie Grangera, sformułowany zostanie model wektorowej autoregresji VAR. Jest to wielorównaniowy model ekonometryczny, w którym brak jest zależności jednoczesnych (współzależności), a zestaw zmiennych objaśniających składa się tylko z procesów opóźnionych w czasie. Modele VAR pozwalają na uzyskanie oszacowania funkcji odpowiedzi impulsowych. Pokazują one bieżące i opóźnione efekty szoku (o wielkości jednego błędu standardowego reszt) na wartości modelowanych zmiennych. Funkcje impulse response zostana tu wykorzystane do opisu skutku szoku (polegającego na zmianie wartości aktywów znajdujących się w bilansie FED) na kształtowanie się kursu wybranych walut.

\section{ANALIZA SZEREGÓW}

Do badań wykorzystano szeregi kursów pięciu walut: Australii, Brazylii, Kanady, Indii i Japonii. Rupia indyjska i real brazylijski zostały wybrane ze względu na to, że jako waluty krajów rozwijających się mogą dostarczyć

${ }^{11}$ C. W. J. Granger, Investigating Casual Relations by Econometric Models and Cross-Spectral Methods, „Econometrica” 37, 1969, nr 3, s. 24-36.

${ }^{12}$ G. S. Maddala, Ekonometria, WN PWN, Warszawa 2008, s. 432-433. 
informacji o wpływie amerykańskiej polityki quantitative easing na kursy walut państw reprezentujacych rynki wschodzące (są to dwa spośród krajów tzw. BRIC). Waluty Australii i Kanady (dolar australijski i dolar kanadyjski) reprezentują państwa znajdujące się w bliskich relacjach gospodarczo-handlowych ze Stanami Zjednoczonymi. W badaniu uwzględniono również walutę Japonii (jen japoński). Rozwinięta gospodarka Japonii może stanowić bazę porównań dla pozostałych wyników. Dzienne kursy walut pochodzą z bazy danych Rezerwy Federalnej ${ }^{13}$.

Wszystkie szeregi kursów walut, z wyjątkiem waluty australijskiej, prezentowane sa jako cena 1 USD wyrażona w walucie obcej, dlatego dla ujednolicenia interpretacji i zwiększenia przejrzystości dokonano modyfikacji szeregu kursu dolara australijskiego. W tym przypadku analizowane sa stopy zwrotu z przeciwnym znakiem. Opis wykorzystanych szeregów danych zilustrowany jest w tabeli 1. Kształtowanie się kursów walut oraz stóp zwrotu w badanym okresie przedstawia wykres 1 oraz 2.

Niestandardowe działania Rezerwy Federalnej w odpowiedzi na kryzys finansowy spowodowały znaczace zmiany w bilansie tej instytucji. Wzrost wartości aktywów w postaci papierów wartościowych (zarówno obligacje agencyjne ABS, obligacje zabezpieczone hipotekami MBS oraz obligacje rządowe) znajdujacych się w posiadaniu Rezerwy Federalnej oznacza zasilenie rynku finansowego o określoną kwotę. Informacje o strukturze bilansu FED ogłaszane sa tygodniowo. Na podstawie danych o papierach wartościowych posiadanych przez FED (securities held outright) obliczono również szereg logarytmicznych procentowych przyrostów (DLSHO.T). Dokonano również agregacji dziennych zwrotów kursów walut do tygodniowych zwrotów i uzyskano szeregi o tej samej częstotliwości i długości. Kształtowanie się tygodniowych zwrotów kursów walut oraz procentowych przyrostów wartości aktywów FED ilustruje wykres 3.

Tabela 1

Opis szeregów będących przedmiotem badań

\begin{tabular}{|c|l|l|l|}
\hline $\begin{array}{c}\text { Nazwa } \\
\text { szeregu }\end{array}$ & \multicolumn{1}{|c|}{ Kurs walutowy } & Zakres czasowy & $\begin{array}{c}\text { Interpretacja ekonomiczna } \\
\text { stóp zwrotu }\end{array}$ \\
\cline { 1 - 2 } AUS & $\begin{array}{l}\text { USD za 1 AUD } \\
\text { (z przeciwnym znakiem) }\end{array}$ & \multirow{2}{*}{ od 01.01.2003 } & $\begin{array}{l}\text { dodatni zwrot - umocnienie USD } \\
\text { ujemny zwrot - osłabienie USD }\end{array}$ \\
\cline { 1 - 2 } BRA & BRL za 1 USD & & \\
\cline { 1 - 2 } CAN & CAD za 1 USD & & \\
\cline { 1 - 2 } IND & INR za 1 USD & JPY za 1 USD &
\end{tabular}

Źródło: opracowanie własne.

${ }_{13}$ Zob. http://www.federalreserve.gov/econresdata/statisticsdata.htm. 
Dla analizowanych danych przeprowadzono testy pozwalające opisać charakterystyki 11 szeregów i ustalić model, który zostanie wykorzystany w późniejszym badaniu. Do analizy zarówno dziennych, jak i tygodniowych zwrotów wykorzystano pakiet OxMetrics. Interpretacje wyników są następujące:

- wyniki testu Jarque'a-Bery pozwalaja na odrzucenie hipotezy zerowej o normalności rozkładu dziennych i tygodniowych stóp zwrotu we wszystkich szeregach;

- wszystkie szeregi cechowała wysoka wartość nadwyżkowej kurtozy (od 2 do 116);

- wyniki testu Boxa-Pierce'a (którego hipoteza zerowa mówi o braku autokorelacji w szeregu) zarówno dla stóp zwrotu, jak i ich kwadratów pozwalaja na odrzucenie hipotezy zerowej jedynie w przypadku tygodniowych zwrotów szeregu IND i dziennych zwrotów szeregu JAP; autokorelacja w kwadratach stóp występuje dla wszystkich szeregów;

- statystyki testowe pozwalają również odrzucić hipotezę zerową o braku występowania efektu ARCH w badanych szeregach;

- test ADF (którego hipoteza zerowa zakłada zintegrowanie szeregu w stopniu pierwszym, a więc jego niestacjonarność) pozwala wnioskować (na poziomie istotności $\alpha=5 \%$ ) o stacjonarności wszystkich szeregów.

\section{WYNIKI BADAŃ}

Stworzono sztuczne zmienne zero-jedynkowe (dummy), które przyjmuja wartość 1, gdy w danym okresie stosowano quantitative easing jako instrument niestandardowej polityki pieniężnej Rezerwy Federalnej. Poszczególne etapy wyróżniono, tworząc trzy zmienne:

- q1 - przyjmująca wartość $1 \mathrm{w}$ okresie od listopada 2008 r. do końca marca 2010 r.,

- q2 - przyjmująca wartość $1 \mathrm{w}$ okresie od listopada 2010 r. do końca czerwca 2011 r.,

- q3 - przyjmujacca wartość $1 \mathrm{w}$ okresie od września 2012 r. do końca grudnia $2013 \mathrm{r}$.

Zmienne $q 1, q 2$ i $q 3$ wprowadzono w sposób egzogeniczny do modeli ARMA-GARCH oszacowanych dla dziennych stóp zwrotu z kursów walut. Istotność oszacowania parametru sztucznej zmiennej oznacza znaczący statystycznie wpływ niestandardowych instrumentów Rezerwy Federalnej na średnią stopę zwrotu lub na zmienność kursu waluty w okresie jednej z faz QE.

Model ze sztucznymi zmiennymi pozwala dostrzec następujące zależności występujace w okresach stosowania przez Rezerwę Federalną niestandardowych instrumentów:

- w okresie stosowania pierwszej fazy quantitative easing brak jest systematycznego wpływu na umocnienie lub osłabienie walut, jednak zauważyć można wzrost zmienności kursów walut Brazylii i Indii; 
- w okresie stosowania drugiej fazy quantitative easing dostrzec można jedynie zwiększoną zmienność kursu rupii indyjskiej;

- w okresie stosowania Q3 waluty Brazylii i Japonii odnotowywały dodatni dzienny zwrot przekładający się na systematyczną deprecjacje tych walut w stosunku do USD; jednocześnie zmienność kursów walut Brazylii i Kanady zmniejszyła się, podczas gdy zmienność kursu rupii nadal pozostawała zwiększona.

Oszacowania parametrów oraz ich istotność w modelu przedstawione zostały w tabeli 2. Do kolejnego modelu wykorzystano tygodniowe zwroty oraz tygodniowe zmiany wartości papierów wartościowych Rezerwy Federalnej (DLSHO). Dodatkowe sztuczne zmienne przyjmowały wartość $D L S H O$ w tych tygodniach, w których poszczególne fazy działań z zakresu quantitative easing były podejmowane, natomiast w pozostałych tygodniach przyjmowały wartość zero. Dodatkowo dla jednego z szeregów skonstruowano zmienna przyjmująca wartości $D L S H O$ w każdej fazie stosowania QE (oraz przyjmująca zero w pozostałych tygodniach).

Tabela 2

Oszacowania parametrów przy zmiennych objaśniających (sztuczne zmienne w modelach kursów walut) i ich $p$-wartości

\begin{tabular}{|c|c|c|c|c|c|c|c|}
\hline \multirow{2}{*}{$\begin{array}{l}\text { Szereg } \\
\text { zwrotów }\end{array}$} & \multirow{2}{*}{ Model } & \multicolumn{3}{|c|}{$\begin{array}{c}\text { Zmienne w równa- } \\
\text { niu średniej }\end{array}$} & \multicolumn{3}{|c|}{$\begin{array}{l}\text { Zmienne w równaniu } \\
\text { wariancji }\end{array}$} \\
\hline & & $q 1$ & $q 2$ & $q 3$ & $q 1$ & $q 2$ & $q 3$ \\
\hline DLAUS & $\begin{array}{l}\text { GARCH }(1,1) \text { rozkład } \\
\text { błędu: skośny } \\
t \text {-Studenta }\end{array}$ & - & - & - & - & - & - \\
\hline DLBRA & $\begin{array}{l}\text { GARCH }(1,1) \text { rozkład } \\
\text { błędu: skośny } \\
t \text {-Studenta }\end{array}$ & - & - & $\begin{array}{c}+ \\
0,043426 \\
(0,0875)\end{array}$ & $\begin{array}{c}+ \\
0,029934 \\
(0,0464)\end{array}$ & - & $\begin{array}{c}+ \\
-0,009936 \\
(0,0462)\end{array}$ \\
\hline DLCAN & $\begin{array}{l}\operatorname{ARMA}(1,1) \\
\operatorname{GARCH}(1,1) \text { rozkład } \\
\text { błędu: } t \text {-Studenta }\end{array}$ & - & - & - & - & - & $\begin{array}{c}+ \\
-0,002386 \\
(0,0251)\end{array}$ \\
\hline DLIND & $\begin{array}{l}\operatorname{ARMA}(1,1) \\
\text { IGARCH( }(1,1) \text { roz- } \\
\text { kład błędu: skośny } \\
t \text {-Studenta }\end{array}$ & - & - & - & $\begin{array}{c}+ \\
0,019925 \\
(0,0130)\end{array}$ & $\begin{array}{c}+ \\
0,012685 \\
(0,0204)\end{array}$ & $\begin{array}{c}+ \\
0,019849 \\
(0,0258)\end{array}$ \\
\hline DLJAP & $\begin{array}{l}\operatorname{ARMA}(0,1) \\
\operatorname{GARCH}(1,1) \text { rozkład } \\
\text { błędu: } t \text {-Studenta }\end{array}$ & - & - & $\begin{array}{c}+ \\
0,087462 \\
(0,0039)\end{array}$ & - & - & - \\
\hline
\end{tabular}

Uwagi: szczegółowa specyfikacja modelu znajduje się w aneksie; w nawiasach podano wartość $p$ dla parametru; modele oszacowane zgodnie ze specyfikacją stosowaną w OxMetrics.

Źródło: opracowanie własne. 
Badanie wykazało, że gdy zostanie uwzględniony dwutygodniowy okres opóźnienia między zmianami stanu posiadania papierów wartościowych a zmianami kursu, zależności wynikające z modelu są następujące:

- wzrost wartości zakupionych przez FED papierów wartościowych w pierwszej fazie QE wpływa na aprecjacje walut Australii, Brazylii, i Indii (oraz w pewnym stopniu Kanady) oraz na deprecjację jena japońskiego;

- wzrost wartości zakupionych przez FED papierów wartościowych w drugiej fazie QE wpływa na aprecjację dolara australijskiego, jena japońskiego (oraz w pewnym stopniu dolara kanadyjskiego);

- w trzeciej fazie działań z zakresu QE wzrost wartości zakupionych papierów wartościowych wpływa na deprecjację dolara australijskiego;

- nie istnieje zwiazek między zmiennością wartości posiadanych papierów wartościowych a zmiennością kursów walut w każdej fazie QE (badanych zmienne w równaniu wariancji kursów walut są nieistotne).

Oszacowania parametrów oraz ich istotność w modelu przedstawione zostały w tabeli 3.

Tabela 3

Oszacowania parametrów przy zmiennych objaśniających (sztuczne zmienne z opóźnieniem o 2 okresy) i ich $p$-wartości

\begin{tabular}{|c|c|c|c|c|c|}
\hline \multirow{2}{*}{$\begin{array}{l}\text { Szereg } \\
\text { zwrotów }\end{array}$} & \multirow[b]{2}{*}{ Model } & \multicolumn{4}{|c|}{ Zmienne w równaniu średniej } \\
\hline & & $\underset{D L S H O}{q 1_{-}}$ & $\underset{D L S H O}{q 2_{-}}$ & $\underset{D L S H O}{q 3_{-}}$ & $\begin{array}{c}q 123_{-} \\
D L S H O\end{array}$ \\
\hline DLAUS & $\begin{array}{l}\text { GARCH }(1,1) \text { rozkład } \\
\text { błędu: skośny } t \text {-Studenta }\end{array}$ & $\begin{array}{c}+ \\
-0,174404 \\
(0,0506)\end{array}$ & $\begin{array}{c}+ \\
-0,533088 \\
(0,0717)\end{array}$ & $\begin{array}{c}+ \\
+0,235347 \\
(0,0856)\end{array}$ & \\
\hline DLBRA & $\begin{array}{l}\text { GARCH }(1,1) \text { rozkład } \\
\text { błędu: skośny } t \text {-Studenta }\end{array}$ & $\begin{array}{c}+ \\
-0,210119 \\
(0,0142)\end{array}$ & - & - & \\
\hline DLCAN & $\begin{array}{l}\operatorname{ARMA}(1,1) \operatorname{IGARCH}(1,1) \\
\text { rozkład błędu: skośny } \\
t \text {-Studenta }\end{array}$ & - & - & - & $\begin{array}{c}+ \\
-0,096945 \\
(0,0405)\end{array}$ \\
\hline DLIND & $\begin{array}{l}\operatorname{ARMA}(1,1) \operatorname{IGARCH}(1,1) \\
\text { rozkład błędu: } t \text {-Studenta }\end{array}$ & $\begin{array}{c}+ \\
-0,048247 \\
(0,0362)\end{array}$ & - & - & \\
\hline DLJAP & $\begin{array}{l}\operatorname{ARMA}(1,1) \text { IGARCH}(1,1) \\
\text { rozkład błędu: } t \text {-Studenta }\end{array}$ & $\begin{array}{c}+ \\
0,065441 \\
(0,0297)\end{array}$ & $\begin{array}{c}+ \\
-0,351376 \\
(0,0971)\end{array}$ & - & \\
\hline
\end{tabular}

Uwagi: szczegółowa specyfikacja modelu znajduje się w aneksie; w nawiasach podano wartość $p$ dla parametru; modele oszacowane zgodnie ze specyfikacją stosowaną w OxMetrics.

Źródło: opracowanie własne. 
Zadano również zagadnienie występowania przyczynowości między szeregami zwrotów z kursów analizowanych walut oraz procentowymi zmianami wartości posiadanych przez Rezerwę Federalną papierów wartościowych (DLSHO). Testowano jednokierunkowa przyczynowość w sensie Grangera: DLSHO jako przyczyna szeregów tygodniowych zwrotów kursów walut. Dla poszczególnych szeregów stworzono model z dwoma opóźnieniami o postaci:

$$
y_{\tau}=\alpha_{1} y_{\tau-1}+\alpha_{2} y_{\tau-2}+\beta_{1} \mathrm{DLSHO}_{\tau-1}+\beta_{2} \mathrm{DLSHO}_{\tau-2}+\varepsilon_{\tau},
$$

gdzie $\mathcal{E}_{\tau}$ oznacza składnik losowy $\mathrm{z}$ modelu. Testowanie przyczynowości $\mathrm{w}$ tym modelu sprowadza się do oceny istotności oszacowań parametrów $\beta_{1}$ i $\beta_{2}$, co zrobiono z wykorzystaniem statystyki F. Test Grangera wykonano $\mathrm{w}$ podziale horyzontu badawczego na dwie próby: momentem rozdzielajacym je jest początek pierwszej fazy stosowania quantitative easing przez Rezerwę Federalna.

Badanie szeregów z użyciem testu przyczynowości Grangera pozwala na wyciagnięcie na podstawie danych z tabeli 4 następujących wniosków:

- na poziomie istotności $\alpha=5 \%$ zmiany wartości posiadanych aktywów można uznać za przyczynę w sensie Grangera kształtowania się kursu dolara australijskiego zarówno przed kryzysem i w początkowych jego miesiaccach, jak i w okresie stosowania przez FED niestandardowych instrumentów;

- zmiany stanu aktywów FED stanowią również przyczynę w sensie Grangera dla stóp zwrotu waluty brazylijskiej w okresie stosowania niestandardowego instrumentu polityki pieniężnej (quantitative easing);

- nie istnieje zależność przyczynowa, zarówno w pierwszej, jak i drugiej próbie, w odniesieniu do walut Kanady, Indii i Japonii.

Tabela 4

Wyniki testu przyczynowości Grangera w rozbiciu na dwie próby

\begin{tabular}{|c|l|l|}
\hline $\begin{array}{c}\text { Szereg } \\
\text { zwrotów }\end{array}$ & \multicolumn{1}{|c|}{$\begin{array}{c}\text { Statystyka testu Grangera } \\
\mathbf{0 1 . 0 1 . 2 0 0 3}-\mathbf{1 9 . 1 1 . 2 0 0 8}\end{array}$} & $\begin{array}{c}\text { Statystyka testu Grangera } \\
\mathbf{2 6 . 1 1 . 2 0 0 8} \mathbf{- 2 5 . 1 2 . 2 0 1 3}\end{array}$ \\
\hline DLAUS & $\mathrm{F}(2,299)=4,4384[0,0126]$ & $\mathrm{F}(2,264)=3,1595[0,0441]$ \\
\hline DLBRA & $\mathrm{F}(2,299)=2,1966[0,1130]$ & $\mathrm{F}(2,264)=5,9233[0,0030]$ \\
\hline DLCAN & $\mathrm{F}(2,299)=2,1327[0,1203]$ & $\mathrm{F}(2,264)=2,1399[0,1197]$ \\
\hline DLIND & $\mathrm{F}(2,299)=1,5220[0,2200]$ & $\mathrm{F}(2,264)=0,85129[0,4280]$ \\
\hline DLJAP & $\mathrm{F}(2,299)=2,0332[0,1327]$ & $\mathrm{F}(2,264)=2,2805[0,1042]$ \\
\hline
\end{tabular}

Uwagi: modele ze stałą i dwoma opóźnieniami zmiennych endogenicznych; w nawiasach podano wartość $p$ dla statystyki.

Źródło: opracowanie własne. 
Biorąc pod uwagę wyniki badania przyczynowości Grangera, oszacowano dwa modele wektorowej autoregresji VAR uwzględniające obserwacje z drugiej próby (okres stosowania QE). W modelu brak jest zależności jednoczesnych (współzależności), a zestaw zmiennych objaśniających składa się z opóźnionych o dwa okresy obserwacji o częstotliwości tygodniowej. Specyfikacja równań modelu pierwszego jest następująca:

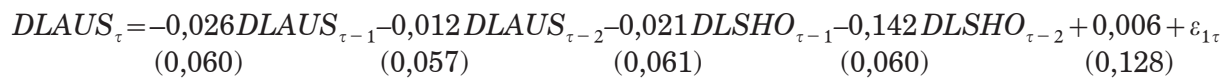

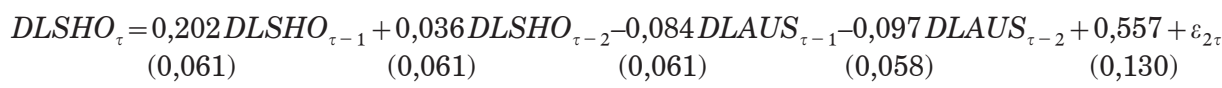

a modelu drugiego następująca:

$$
\begin{aligned}
& D_{L B R A_{\tau}}=-0,158 D L B R A_{\tau-1}+0,031 D_{L B R A_{\tau-2}}+0,005 \text { DLSHO }_{\tau-1}-0,224 \text { DLSHO }_{\tau-2}+0,201+\varepsilon_{3 \tau} \\
& \begin{array}{lllll}
(0,058) & (0,056) & (0,067) & (0,066) & (0,142)
\end{array} \\
& \mathrm{DLSHO}_{\tau}=0,202 \mathrm{DLSHO}_{\tau-1}+0,041 \mathrm{DLSHO}_{\tau-2}-0,102 \mathrm{DLBRA}_{\tau-1}-0,102 \mathrm{DLBRA}_{\tau-2}+0,578+\varepsilon_{4 \tau} \\
& \begin{array}{lllll}
(0,061) & (0,061) & (0,053) & (0,051) & (0,130)
\end{array}
\end{aligned}
$$

W nawiasach podano błędy standardowe oszacowań parametrów. Modele wykorzystano do zobrazowania funkcji odpowiedzi na impuls (impulse response functions) przedstawionych na wykresie. Funkcje reakcji DLAUS i DLSHO na impuls czynnika $D L S H O$ (zamieszczone na wykresie 4) potwierdzaja wyniki uzyskane z modeli GARCH ze sztucznymi zmiennymi $q 1 \_D L S H O, q 2 \_D L S H O$ i $q 3 \_D L S H O$. W okresie stosowania niestandardowych instrumentów typu QE impuls w postaci zwiększenia wartości zakupionych papierów wartościowych powoduje aprecjację walut Australii i Brazylii i osłabienie dolara amerykańskiego z opóźnieniem szacowanym na dwa tygodnie. Po tym okresie impuls wygasa.

$$
* * *
$$

Na podstawie dokonanych analiz autorka wysuwa wniosek o statystycznie istotnym wpływie działań podjętych przez Rezerwę Federalną na kursy walut, w szczególności Australii i Brazylii. Zmiany stanu bilansowego aktywów stanowiły bowiem przyczynę w sensie Grangera dla kształtowania się zmian kursu dolara australijskiego i reala brazylijskiego w okresie od momentu wdrożenia programu zakupu papierów wartościowych. Sformułowane na podstawie tej obserwacji modele VAR pozwalają wyciagnać wniosek o spadku wartości dolara amerykańskiego w wyniku działań z zakresu quantitative easing. Zależność ta nie została potwierdzona w odniesieniu do pozostałych walut.

Badania mające na celu porównanie między sobą efektów wywołanych przez poszczególne fazy polityki zakupu aktywów wskazują na występowanie podobnego kierunku zmian badanych kursów walut w pierwszej i drugiej fazie QE, natomiast przeciwnych zmian kursów walut w trzeciej fazie QE. Podczas pierwszej i drugiej fazy QE wzrost wartości zakupionych aktywów przyczyniał się do aprecjacji walut: Australii (w obu fazach), Brazylii i Indii (w pierwszej fazie) oraz Kanady (w drugiej fazie). Reakcja waluty Japonii odstaje od pozostałych badanych walut w fazie QE1 (efekt deprecjacji waluty w wyniku wzro- 
stu aktywów FED), lecz nie w fazie QE2. Analogiczny czynnik zmiany wartości papierów wartościowych wywołał efekt spadku wartości dolara australijskiego w trzeciej fazie QE. Ponadto w tym okresie również waluty Brazylii i Japonii podlegały presji spadku wartości, jednak niebędącej wynikiem działań FED.

W przypadku walut Australii i Japonii nie następuje zróżnicowanie intensywności wahań kursu między fazami QE. W przypadku waluty Brazylii zmienność kursu jest podwyższona w fazie QE1, natomiast zmniejsza się w fazie QE3. Podczas trwania fazy trzeciej zmniejsza się również intensywność wahań kursu dolara kanadyjskiego. W odróżnieniu od reala brazylijskiego i dolara kanadyjskiego jen japoński odnotowuje zwiększenie wahań kursu, w odniesieniu do wartości przedkryzysowych, we wszystkich trzech fazach działań QE.

Wyniki badań poszczególnych walut nie pozwalają na stworzenie wspólnego modelu reakcji na zasilające rynek finansowy działania FED. Dokonana analiza stanowi jednak przyczynek do dalszych badań nad efektami polityki quantitative easing na rynki walutowe.

dr Hanna Kołodziejczyk

Uniwersytet Ekonomiczny w Poznaniu

hanna.kolodziejczyk@ue.poznan.pl

EXAMINATION OF THE IMPACT OF THE FEDERAL RESERVE'S QUANTITATIVE EASING ON SELECTED EXCHANGE RATES

Summary

This paper examines the impact of implementing Large Scale Asset Purchases by the Federal Reserve on selected exchange rates, using statistical and econometrical methods, including GARCH models. There is limited statistical evidence suggesting that the increase of asset purchases is a significant factor in explaining exchange rate returns of Australian dollar, Brazilian real, Canadian dollar, Indian rupee and Japanese yen. Evidence also suggests that during the first and second phase of quantitative easing foreign currencies have strengthened due to Federal Reserves' asset purchase program. 


\section{ANEKS}

Wykres 1

Dzienne notowania kursów wybranych walut
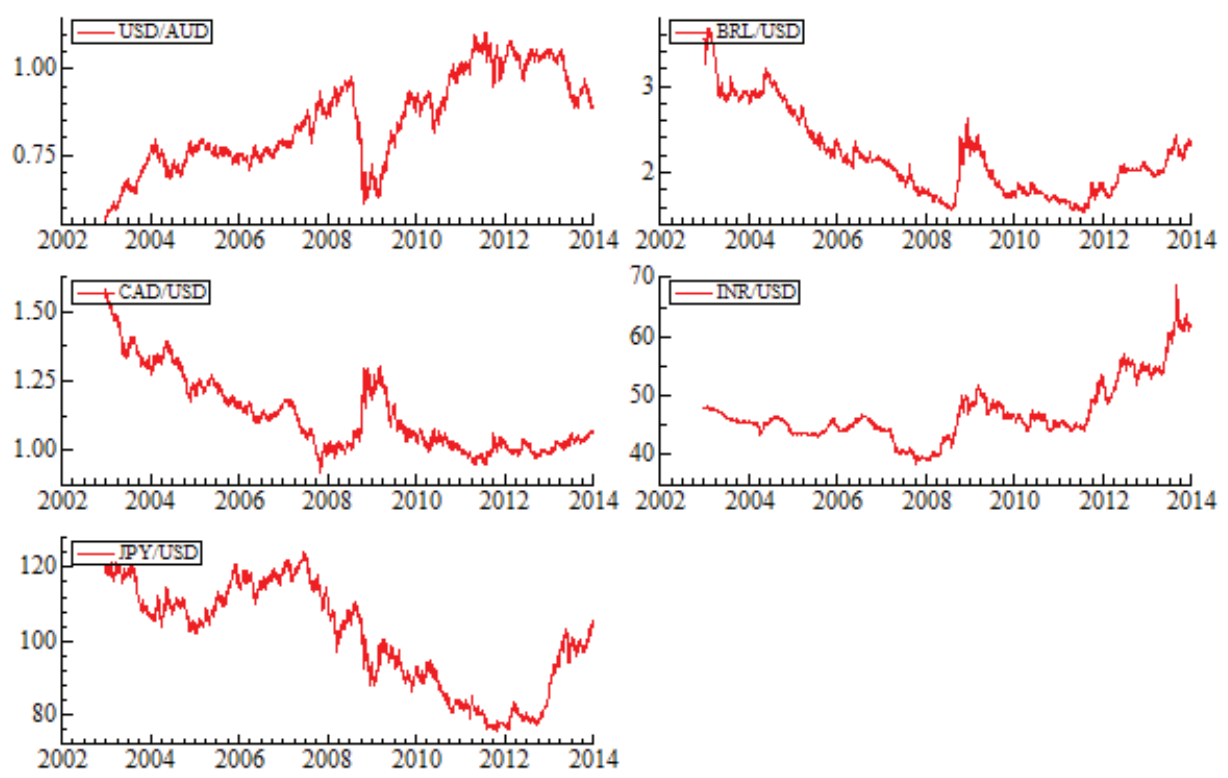

Źródło: opracowanie własne.

Wykres 2

Dzienne procentowe logarytmiczne zwrotu z kursów walut
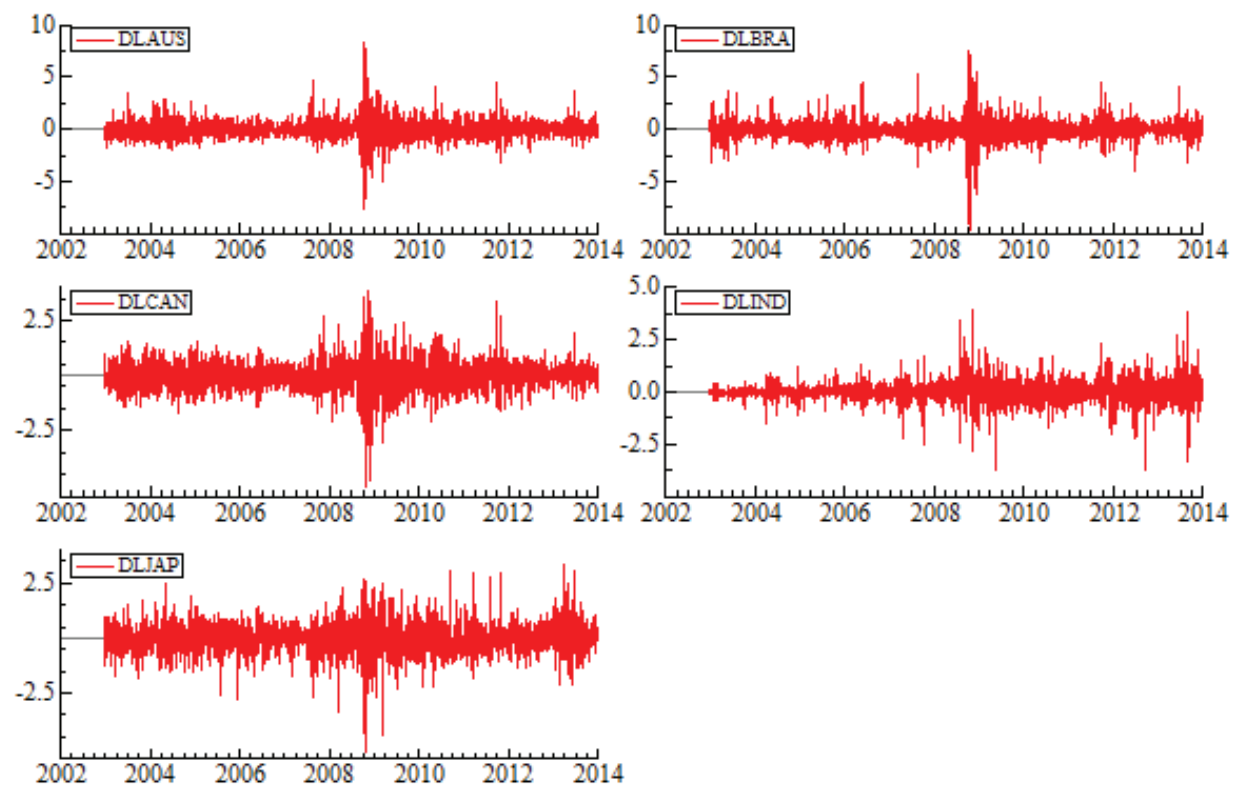

Źródło: opracowanie własne. 


\section{Wykres 3}

Zagregowane, tygodniowe procentowe logarytmiczne zwroty dla poszczególnych szeregów
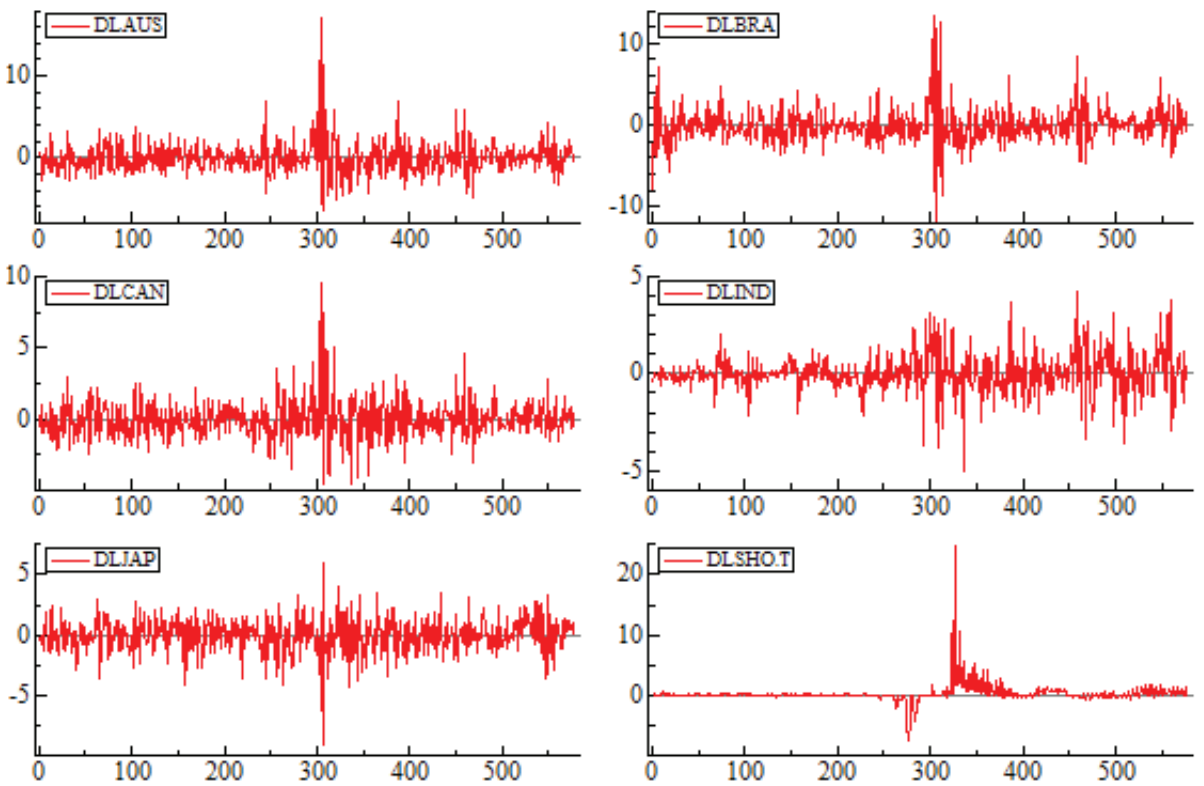

Źródło: opracowanie własne.

\section{Wykres 4}

Funkcje impulse response - reakcja zwrotów z AUS (z lewej) i BRA (z prawej) na impuls DLSHO
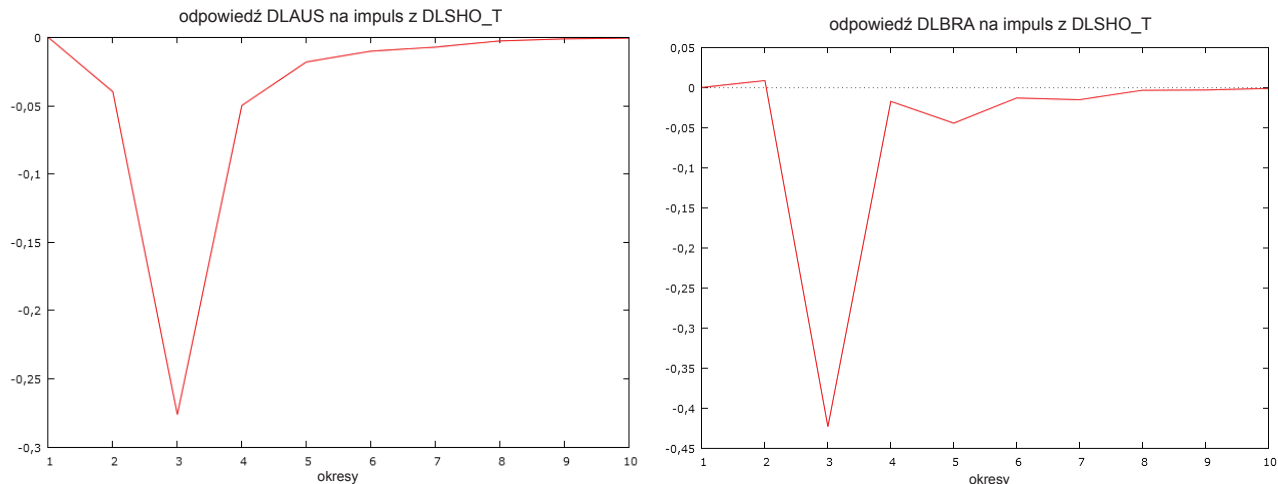

Źródło: opracowanie własne. 


\section{Tabela 5}

Oszacowane parametry modeli z tabeli 1

\begin{tabular}{|c|c|c|c|c|c|}
\hline & DLAUS & DLBRA & DLCAN & DLIND & DLJAP \\
\hline $\begin{array}{l}\text { AR } 1 \\
\text { (a1) }\end{array}$ & & & $\begin{array}{l}0,632454 \\
(0,086900)\end{array}$ & $\begin{array}{l}0,229953 \\
(0,10433)\end{array}$ & \\
\hline $\begin{array}{l}\text { MA } 1 \\
\text { (b1) }\end{array}$ & & & $\begin{array}{l}-0,635379 \\
(0,091931)\end{array}$ & $\begin{array}{l}-0,322717 \\
(0,10078)\end{array}$ & $\begin{array}{l}-0,042915 \\
(0,019171)\end{array}$ \\
\hline q3 (M) & & $\begin{array}{l}0,043426 \\
(0,025402)\end{array}$ & & & $\begin{array}{l}0,087462 \\
(0,030303)\end{array}$ \\
\hline $\begin{array}{l}\operatorname{Cst}(V) \\
(\omega)\end{array}$ & $\begin{array}{l}0,004707 \\
(0,0016903)\end{array}$ & $\begin{array}{l}0,017289 \\
(0,0051686)\end{array}$ & $\begin{array}{l}0,003536 \\
(0,0012083)\end{array}$ & $\begin{array}{l}0,001901 \\
(0,00064260)\end{array}$ & $\begin{array}{l}0,004917 \\
(0,0020172)\end{array}$ \\
\hline $\mathrm{q} 1(\mathrm{~V})$ & & $\begin{array}{l}0,029934 \\
(0,015021)\end{array}$ & & $\begin{array}{l}0,019925 \\
(0,0080211)\end{array}$ & \\
\hline q2(V) & & & & $\begin{array}{l}0,012685 \\
(0,0054665)\end{array}$ & \\
\hline q3 (V) & & $\begin{array}{l}-0,009936 \\
(0,0049829)\end{array}$ & $\begin{array}{l}-0,002386 \\
(0,0010646)\end{array}$ & $\begin{array}{l}0,019849 \\
(0,0088999)\end{array}$ & \\
\hline $\begin{array}{l}\mathrm{ARCH} \\
\text { (a1) }\end{array}$ & $\begin{array}{l}0,046671 \\
(0,0075981)\end{array}$ & $\begin{array}{l}0,134028 \\
(0,018131)\end{array}$ & $\begin{array}{l}0,043037 \\
(0,0058799)\end{array}$ & $\begin{array}{l}0,162889 \\
(0,029353)\end{array}$ & $\begin{array}{l}0,034379 \\
(0,0083919)\end{array}$ \\
\hline $\begin{array}{l}\text { GARCH } \\
(B 1)\end{array}$ & $\begin{array}{l}0,946741 \\
(0,0080241)\end{array}$ & $\begin{array}{l}0,850302 \\
(0,019475)\end{array}$ & $\begin{array}{l}0,948277 \\
(0,0064982)\end{array}$ & 0,837111 & $\begin{array}{l}0,954195 \\
(0,011295)\end{array}$ \\
\hline $\begin{array}{l}\text { AS } \\
\text { (asymetria) }\end{array}$ & $\begin{array}{l}0,174010 \\
(0,027463)\end{array}$ & $\begin{array}{l}0,123083 \\
(0,026866)\end{array}$ & & $\begin{array}{l}0,045228 \\
(0,019873)\end{array}$ & \\
\hline $\begin{array}{l}\text { DF } \\
\text { (stopnie swobody) }\end{array}$ & $\begin{array}{l}9,002992 \\
(1,4683)\end{array}$ & $\begin{array}{l}7,461514 \\
(1,0556)\end{array}$ & $\begin{array}{l}9,830198 \\
(1,8694)\end{array}$ & $\begin{array}{l}3,887704 \\
(0,22501)\end{array}$ & $\begin{array}{l}5,770097 \\
(0,64466)\end{array}$ \\
\hline
\end{tabular}

Uwagi: w nawiasach podano błędy standardowe; modele oszacowane zgodnie ze specyfikacją stosowana w OxMetrics.

Źródło: opracowanie własne. 
Tabela 6

Oszacowane parametry modeli z tabeli 2

\begin{tabular}{|c|c|c|c|c|c|}
\hline & DLAUS & DLBRA & DLCAN & DLIND & DLJAP \\
\hline q1_DLSHO_2 (M) & $\begin{array}{l}-0,174404 \\
(0,089033)\end{array}$ & $\begin{array}{l}-0,210119 \\
(0,085427)\end{array}$ & & $\begin{array}{l}-0,048247 \\
(0,022984)\end{array}$ & $\begin{array}{l}0,065441 \\
(0,030025)\end{array}$ \\
\hline q2_DLSHO_2 (M) & $\begin{array}{l}-0,533088 \\
(0,29544)\end{array}$ & & & & $\begin{array}{l}-0,351376 \\
(0,21143)\end{array}$ \\
\hline q3_DLSHO_2 (M) & $\begin{array}{l}0,235347 \\
(0,13667)\end{array}$ & & & & \\
\hline $\begin{array}{l}\text { q123_DLSHO_2 } \\
\text { (M) }\end{array}$ & & & $\begin{array}{l}-0,096945 \\
(0,047219)\end{array}$ & & \\
\hline $\begin{array}{l}\text { AR } 1 \\
\text { (a1) }\end{array}$ & & & $\begin{array}{l}0,520919 \\
(0,20407)\end{array}$ & $\begin{array}{l}0,834201 \\
(0,20579)\end{array}$ & $\begin{array}{l}-0,988997 \\
(0,030491)\end{array}$ \\
\hline $\begin{array}{l}\text { MA } 2 \\
\text { (b1) }\end{array}$ & & & $\begin{array}{l}-0,571874 \\
(0,19117)\end{array}$ & $\begin{array}{l}-0,779543 \\
(0,23951)\end{array}$ & $\begin{array}{l}0,976185 \\
(0,044250)\end{array}$ \\
\hline $\begin{array}{l}\operatorname{Cst}(V) \\
(\omega)\end{array}$ & $\begin{array}{l}0,164160 \\
(0,071189)\end{array}$ & $\begin{array}{l}0,281254 \\
(0,10371)\end{array}$ & & & \\
\hline $\begin{array}{l}\mathrm{ARCH} \\
\text { (a1) }\end{array}$ & $\begin{array}{l}0,105642 \\
(0,031972)\end{array}$ & $\begin{array}{l}0,181541 \\
(0,039007)\end{array}$ & $\begin{array}{l}0,071664 \\
(0,021726)\end{array}$ & $\begin{array}{l}0,136145 \\
(0,035664)\end{array}$ & $\begin{array}{l}0,037691 \\
(0,018077)\end{array}$ \\
\hline $\begin{array}{l}\text { GARCH } \\
\text { (B1) }\end{array}$ & $\begin{array}{l}0,845533 \\
(0,042425)\end{array}$ & $\begin{array}{l}0,748000 \\
(0,042561)\end{array}$ & 0,928336 & 0,863855 & 0,962309 \\
\hline $\begin{array}{l}\text { AS } \\
\text { (asymetria) }\end{array}$ & $\begin{array}{l}0,384988 \\
(0,063276)\end{array}$ & $\begin{array}{l}0,259168 \\
(0,049285)\end{array}$ & $\begin{array}{l}0,183587 \\
(0,065995)\end{array}$ & & \\
\hline $\begin{array}{l}\text { DF } \\
\text { (stopnie swobody) }\end{array}$ & $\begin{array}{l}8,323093 \\
(2,6263)\end{array}$ & $\begin{array}{l}7,815799 \\
(2,3357)\end{array}$ & $\begin{array}{l}10,515360 \\
(3,1648)\end{array}$ & $\begin{array}{l}4,672179 \\
(0,57544)\end{array}$ & $\begin{array}{l}7,909542 \\
(1,8880)\end{array}$ \\
\hline
\end{tabular}

Uwagi: w nawiasach podano błędy standardowe; modele oszacowane zgodnie ze specyfikacją stosowana w OxMetrics.

Źródło: opracowanie własne. 
Copyright of Journal of Law, Economics and Sociology is the property of Faculty of Law and Administration of Adam Mickiewicz University in Poznan and its content may not be copied or emailed to multiple sites or posted to a listserv without the copyright holder's express written permission. However, users may print, download, or email articles for individual use.

Właścicielem praw autorskich do „Ruchu Prawniczego, Ekonomicznego i Socjologicznego” jest Wydział Prawa i Administracji Uniwersytetu im. Adama Mickiewicza w Poznaniu. Zawartość czasopisma nie może być kopiowana, przesyłana do innych stron internetowych bądź zamieszczana na blogach bez pisemnej zgody wydawcy. Niemniej artykuły można drukować, kopiować lub przesyłać w formie elektronicznej na własny użytek. 